\title{
American Depository Receipts: A Case Study Of The Performance Of Foreign Manufacturing Firm Equities Listed On The New York Stock Exchange
}

R. Stephen Elliott, Northwestern State University Mark Schaub, Northwestern State University

\begin{abstract}
With the growth of free-trade agreements and the development of a global economy, foreign equities may seem to provide a lucrative and diversified alternative for portfolio managers and individual investors. During the study period, all 35 newly issued foreign manufacturing firm equities from 18 countries listed on the New York Stock Exchange traded as American Depository Receipts (ADRs) are examined to determine short term investment performance relative to the market. The Standard \& Poor's 500 Index serves as a proxy for the performance of the market. Data are tested for significant differences in returns during the period of January 1, 1990 to December 31, 2002 during the first 21 days of trading after their initial listing. In addition, the equities are examined to determine whether differences exist in those from emerging and developed countries and whether the timing of issue (in the U.S. bull and bear market) affects returns. Findings suggest no significant difference in the overall short-term performance of the manufacturing firm ADRs relative to the S\&P500 Index during the first 21 days of trading. Further examination indicates that initial public offerings significantly out-perform the market by 5.0 percent and seasoned equity offerings performance is not significantly different from the $S \& P$ 500. Manufacturing firm ADR returns from developed markets and their counterparts from emerging markets show no significant difference from the performance of the market index. However, timing of the issue shows the most dramatic contrast in performance. ADRs issued before 1/1/98, primarily in a bull market, significantly underperformed the market by 26.51 percent. Those issued in the bear market after 1/1/98 show 9 months of returns that are positive and significant during the 36-month holding period. Evidence suggests that initial public offerings and timing of issue may affect manufacturing firm ADR portfolio performance to achieve returns greater than the market.
\end{abstract}

\section{INTRODUCTION}

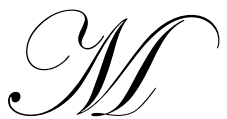

anufacturing firms are capitalizing on global resources from all over the world more than ever before. Companies are outsourcing everything from information technology to engineering to patent attorneys (Engardio and Armdt, 2006). During the last twenty years, exports have increased from 16 percent to 27 percent of total output. Since 1990, foreign direct investment has almost tripled and foreign portfolio investment has risen fivefold as a percentage of world output. As countries open themselves to international competition, they tend to pursue policies that promote success in the global market. Open economies tend to exhibit innovative policies to help foster new business formation, political stability, accountability, and anticorruption policies (Cox and Alm, 2005).

With the passage of the General Agreement on Tariffs and Trade (GATT), the 149-nation World Trade Organization (WTO), and the North American Free Trade Agreement (NAFTA), world trade more than tripled 
during the period of 1980 to 2001 to 12.5 trillion (Cox and Alm, 2002). Overall, globalization is reducing costs, creating larger markets, greater specialization, and higher standards of living. Global productivity has nearly doubled in the past ten years to 2.3 percent a year (Cox and Alm, 2006).

Generally, lower prices of substitute goods produced by foreign firms stimulate greater sales, increase revenues and provide the potential for profitable investment returns from foreign equities. One can reasonably assume that growth of foreign trade creates an opportunity for institutional investors and individuals to diversify their portfolios and reap profits. Surz (2007) reports that real diversification benefits come from outside the United States and that equities from most countries outperform the S\&P 500.

To facilitate the trading of foreign equities within the United States, the American Depository Receipts (ADRs) were first introduced by J.P. Morgan in 1927. American Depository Receipts make it possible for investors to buy and sell foreign securities without having to trade on foreign exchanges or deal in foreign currency. The primary advantage for purchasing ADRs is the benefit of global diversification (Officer and Hoffmeister, 1988 and Jiang, 1998).

ADRs are certificates created by large U.S. banks that represent ownership of foreign equity shares denominated in U.S. dollars. The bank holds the original foreign stock in trust and distributes dividends to the ADR owner in U.S. dollars. ADRs are traded on the New York Stock Exchange, the American Stock Exchange, and the over-the-counter market. The market value of the ADR fluctuates with the market value of the underlying foreign stock (Besley and Brigham, 1999). Approximately 1700 ADRs are traded in the United States (Brigham and Ehrhardt, 2005). This study examines the performance of manufacturing firm American Depository Receipts listed on the New York Stock Exchange.

\section{RELATED LITERATURE}

Previous studies show conflicting findings in the performance of ADRs. Callaghan, Kleiman and Sahu (1999) find that ADRs significantly outperform the stock market index during short-term and long-term holding periods from the date of issue. From a sample of 66 ADRs from 18 countries the authors record cumulative excess returns of 19.6 percent during the first 12 months and 2.3 percent cumulative excess returns during the first month. ADRs from emerging markets yield cumulative excess returns of 34.37 percent during the first year and outperform ADRs from developed countries. Sundaram and Logue (1996) also discover significant positive abnormal returns in early trading. Furthermore, Jayaraman, Shastri and Tandon (1993) find the variances of the underlying shares from developed markets to be significantly higher after listing the ADRs.

In a study of 18 Mexican ADRs issued on the NYSE, Schaub (2002) finds that the ADRs outperform the S\&P 500 by 3.8 percent in the first day of trading but under-perform the index during the first five years. In another study, Schaub (2003a) examines early returns of ADRs segmented by date of issue to determine the effects of market-timing. Schaub finds that ADRs issued prior to May 1, 2000 outperform the S\&P 500 by nearly 12 percent in the first month of trading. Those issued after May 1, 2000 underperformed the index by 1.4 percent in the first month of trading. Elliott and Schaub (2005) find long-run returns for financial institution ADRs from developed markets significantly outperformed the S\&P 500 by 15.17 percent while emerging market firms perform similar to the market index. Interestingly, SEOs significantly outperformed the S\&P 500 by 20.69 percent while the IPOs show no significant difference in performance relative to the S\&P 500. According to Schaub (2004), significant cumulative wealth effects associated with stock market timing may exist for IPOs and SEOs trading during holding periods in bear markets. More recently, Schaub (2006) examines long-term returns of 119 emerging market and 123 developed market ADRs listed on the NYSE. He concludes that emerging market ADRs issued prior to January 1, 1998 under-perform the S\&P 500 index during a holding period of 36 months while those issued after January 1, 1998 outperform the S\&P 500 index. Findings suggest that emerging market ADR performance may move countercyclical to the domestic equities. Developed market ADRs under-perform the S\&P 500 index throughout the study period. In a similar study, Surz (2007) finds that from 2000-2006, ADRs earned returns of 32 percent while the S\&P 500 Index earned an average return of 16 percent. 
In a study involving 333 ADRs from 35 countries, Foerster and Karolyi (2000) find ADRs under-perform comparable firms by $8 \%-15 \%$ during the first three years following the date of issue and under-perform the U.S. market index by 27.5 percent during the 3 year holding period. Ritter (1991) also concludes that global equity offerings under-perform the market in the long run. Martell, Rodriguez and Webb (1999) find that price volatility of the underlying shares for ADRs from emerging markets are weak and not significant, while Alexander, Eun, and Janakiramanan (1988) find that foreign equities under-perform the market in the long-run. In addition, Schaub (2003b) finds no significant difference in short-term performance, however he finds that the ADRs under-perform the S\&P 500 Index in the long run. Segmenting the ADRs by equities from emerging markets and developed markets he finds that ADRs from developed markets perform the same as the S\&P 500 index while those from emerging markets under-perform the S\&P 500 index by 2.16 percent during the first month of trading. After three years of trading, emerging market and developed market ADRs under-perform the S\&P 500 index. In related IPO studies with equities from the United Kingdom (Levis, 1993), Taiwan (Huang(1999) and Latin America (Aggarwal, Leal and Hernandez, 1993) and others (Brav and Gompers, 1997) find that initial public offerings from foreign countries generally under-perform the market in the long run. Contrary to these studies Ben Naceur (2000) and Dawson (1987) find that IPOs outperform the market in the long-run.

The literature does not provide a definite answer to the problem of whether newly issued ADRs generate early returns greater than the market and does not specifically examine the performance of manufacturing firm ADRs. Because of their economic importance, this study examines the short-term performance of manufacturing firm ADRs.

\section{THE PROBLEM}

The problem of this study is to determine whether manufacturing firm ADRs newly listed on the New York Stock Exchange generally outperform the S\&P 500 Index over a 21-day period from the date of issue and to determine whether the performance of developed market ADRs differ from those of emerging markets. Furthermore, the problem is to determine whether manufacturing firm ADR returns from initial public offerings (IPOs) differ from seasoned equity offerings (SEOs), and also whether manufacturing firm ADR performance differs because of market-timing.

\section{DATA}

This study examines the short-term performance of foreign manufacturing firm equities traded as American Depository Receipts (ADRs). Daily and monthly cumulative excess (abnormal) returns are examined from a portfolio of 35 manufacturing firm ADRs traded on the New York Stock Exchange from January 1, 1990 through December 31, 2002. A 13-year study period is selected to examine ADR performance during a period that includes both bull and bear markets. Although the portfolio includes a relatively small number of equities, the 35 ADRs span 18 different countries and represent 100 percent of the newly issued foreign manufacturing firm equities listed on the New York Stock Exchange during the study period. To capture more information concerning performance, the 35 ADRs are further segmented into several subsets: 10 from emerging markets, 25 from developed markets; and 21 IPO issues, 14 SEO issues, 19 ADRs listed before 1/1/98 and 16 ADRs listed after 1/1/98. Equity prices and S\&P 500 data were obtained from Commodity Systems, Inc. Table 1 identifies the eighteen countries represented and the number of stock issues from each country.

\section{METHODOLOGY}

The methodology of this study is modeled from earlier studies by Schaub (2003b) and Foerster and Karolyi (2000) by examining ADR daily cumulative excess returns during the first 21-days after the date of issue and monthly cumulative excess returns for 36 months after the date of issue. Performance data is derived from ADRs listed on the New York Stock Exchange. In the case of earlier studies, (Schaub, 2002, 2003a,b) the S\&P 500 Index serves as an appropriate proxy for the U.S. market comparison. 
In the analysis for market timing later in the paper, the cutoff time of 1/1/98 is selected to capture the effects of the market correction on long-term ADR returns. The ADRs listed before 1/1/98 and others listed after 1/1/98 allows testing the performance of manufacturing firm ADRs during a 36-month holding period during a bull market (before the cutoff date) and a bear market (after the cutoff date).

Returns are calculated as compounded total returns including dividends over consecutive days or months. Daily or monthly excess returns are computed by subtracting each day or monthly holding period return from that of the S\&P 500 Index.

Equations 1 through 3 below describe the process for computing excess returns $(x r)$, average excess returns $(A X R)$, and cumulative excess returns $(C X R)$. First, the excess return for each security $i$ on day $t\left(x r_{i, t}\right)$ is computed as the difference between the return of the security on day $t\left(r_{i, t}\right)$ and the return of the S\&P 500 market index on day $t\left(r_{m, t}\right)$.

$$
x r_{i, t}=r_{i, t}-r_{m, t}
$$

In equation 2, the average excess return for the sample for each day $t\left(A X R_{t}\right)$ is derived from the mean of the sum of the excess returns for each of the $n$ securities during day $t$.

$$
A X R_{t}=\frac{1}{n}\left(\sum_{i=1}^{n} x r_{i, t}\right)
$$

Finally, cumulative excess returns as of day $T$ are computed as the summation of the average excess returns starting at day 1 until day $T$.

$$
C X R_{1, T}=\sum_{t=1}^{T} A X R_{t}
$$

P-values for daily average excess returns (AXR) and the cumulative average excess returns (CXR) are calculated and tested for statistical significance using a Z-score to determine significance at the 10 percent alpha level. The respective p-values for these tests are given in Tables 2, 3, and 4. A p-value of .10 or less indicates the excess return or cumulative excess return is significantly different from 0 .

\section{FINDINGS}

As shown in Table 2 in bold print, average excess returns for the entire sample during the 21-day period are significant and positive on days 1, 14, and 17 and significant and negative on days 3 and 4 . However, cumulative excess returns are positive and significant for the first day of trading only. The remaining 20 days show earnings that are not significantly different from the S\&P 500.

Further investigation reveals that a difference in performance seems to exist among IPOs and SEOs. The IPOs show positive and significant average excess returns in days 1,14 , and 17 , while day 3 was negative and significant. Cumulative excess returns are positive and significant on days 1,2,17, 18, 19 and 21. At the end of the holding period, the IPOs earned a significant 5.00 percent cumulative excess return. On the other hand, the SEOs earned negative and significant cumulative excess returns on days 2-14, 16, and 18. Significant cumulative excess returns ranged from a negative 1.85 to a negative 4.46 percent. Overall, the SEOs finished the 21-day holding period with returns that are not significantly different from the performance of the S\&P 500. Findings seem to suggest that manufacturing firm IPOs outperform SEOs.

In Table 3, p-values for average excess returns and cumulative excess returns are shown for emerging market and developed market ADRs. Over the 21-day period, the emerging market ADRs reveal positive and significant average excess returns on days 5,11,17, and negative and significant average excess returns on days 2 , 
6, 19 and 20. Cumulative excess returns for emerging market ADRs are significant and negative on days 2, 3, and 4 and end the 21-day period with no significant difference in returns. The ADRs from developed markets earned positive and significant average excess returns on days 1,6,14,17, and 19. Negative and significant average excess returns are earned on days 3, 4, and 12. Developed market ADR cumulative excess returns are significant only on days 1 and 2 and end the holding period with returns that are not significantly different from the S\&P 500 .

Because diversification is of utmost importance during stock market corrections, market-timing is examined. To determine whether market-timing influences manufacturing firm ADR performance, data are expanded to provide monthly cumulative excess returns over a long-run holding period of 36 months from the data of issue. The results for all 35 ADRs during the entire period and for the 19 ADRs listed before 1/1/98 (bull market) and the 16 ADRs listed after 1/1/98 (bear market) are given in Table 4.

In the left-hand column of Table 4, the entire sample of 35 manufacturing firm ADR monthly average excess returns and cumulative excess returns are shown for the 36-month holding period. Cumulative excess returns are positive and significant for months $2,4,5$, and 6 and are not significant at the end of the 36-month holding period.

The middle column shows the performance for the ADRs listed before 1/1/98 during the bull market. During the holding period, cumulative excess returns are not statistically different from the S\&P 500 during months 1 through 34 , however, cumulative excess returns end the 36-month holding period with a significant and negative return of 26.51 percent. When market-timing is introduced, the data seems to indicate a counter-cyclical behavior.

The right-hand column shows the monthly cumulative excess returns for ADRs during the bear market for those listed after 1/1/98. During months 3-9, 11, and 22, cumulative excess returns are positive and statistically significant and range from 9.64 to 24.09 percent. The 36-month holding period ends with cumulative excess returns that are not significant.

\section{CONCLUSIONS}

Although manufacturing firms represent an important sector of the economy for any country, the evidence from this study does not support the hypothesis that manufacturing firm ADR's outperform the S\&P 500. There is no significant difference in performance of the ADRs relative to the performance of the S\&P 500 Index. These findings are consistent with those of Elliott and Schaub (2005) and Schaub (2003b), and are contrary to those of Callaghan, Kleiman, and Sahu (1999) who find significant excess returns during short and long-term holding periods and Foerster and Karolyi (2000) who find significant underperformance. Evidence, however, indicates that IPOs significantly out-perform the S\&P 500 Index in early trading while no significant difference in performance exists for SEOs. These finding are contrary to the results from financial institution ADRs by Elliott and Schaub (2005). When ADRs are segmented by firms from emerging markets and developed markets, no significant difference exists in performance relative to the S\&P 500 Index during the 21-day holding period. This differs from the findings of Elliott and Schaub (2005) who reveal that financial institution ADRs from developed markets significantly outperform the S\&P 500 in the long-term.

The findings, however, suggest that market-timing is a critical factor. The ADRs listed before 1/1/98, during the domestic bull market, reveal statistically significant negative returns of nearly 26 percent. The significant negative returns during the bull market and significant positive returns in months 3-9, 11, and 22 during the bear market seem to suggest that manufacturing firm ADR returns move counter-cyclical to the S\&P index. This is consistent with the findings of Schaub (2004 and 2006).

Overall, the findings of this study suggest that manufacturing firm ADRs generally perform similar to the S\&P Index. However, IPOs outperform SEOs amd the market in early trading. If these findings are representative of the industry in general, implications are that manufacturing firm ADRs may provide diversification benefits because of their counter-cyclical performance relative to the domestic market. Further study is needed to unravel the mystery of the erratic behavior of ADR performance. 
Table 1

Survey Sample Of All Newly Issued Foreign Manufacturing Industry Equities Listed On The New York Stock Exchange From January 1990 - December 2002 by Country

\begin{tabular}{|c|c|c|c|}
\hline Australia: & $\begin{array}{l}2 \text { Issues } \\
\text { SEOs }\end{array}$ & Italy: & $\begin{array}{l}3 \text { Issues } \\
\text { IPOs }\end{array}$ \\
\hline Brazil: & $\begin{array}{l}2 \text { Issues * } \\
\text { IPOs }\end{array}$ & Japan: & $\begin{array}{l}3 \text { Issues } \\
\text { SEOs }\end{array}$ \\
\hline Chile: & $\begin{array}{l}2 \text { Issues * } \\
\text { IPOs }\end{array}$ & Mexico: & $\begin{array}{l}5 \text { Issues * } \\
\text { (4) IPO } \\
\text { (1) SEO }\end{array}$ \\
\hline Finland: & $\begin{array}{l}2 \text { Issues } \\
\text { SEOs }\end{array}$ & Netherlands: & $\begin{array}{l}1 \text { Issue } \\
\text { IPO }\end{array}$ \\
\hline France: & $\begin{array}{l}2 \text { Issues } \\
\text { (1) IPO, (1) SEO }\end{array}$ & New Zealand: & $\begin{array}{l}1 \text { Issue } \\
\text { SEO }\end{array}$ \\
\hline Germany: & $\begin{array}{l}3 \text { Issues } \\
\text { (2) IPOs, (1) SEO }\end{array}$ & Singapore: & $\begin{array}{l}1 \text { Issue } \\
\text { IPO }\end{array}$ \\
\hline Hong Kong: & $\begin{array}{l}1 \text { Issue } \\
\text { IPO }\end{array}$ & South Africa: & $\begin{array}{l}1 \text { Issue * } \\
\text { SEO }\end{array}$ \\
\hline Ireland: & $\begin{array}{l}1 \text { Issue } \\
\text { SEO }\end{array}$ & Taiwan: & $\begin{array}{l}3 \text { Issues } \\
\text { IPOs }\end{array}$ \\
\hline Israel: & $\begin{array}{l}1 \text { Issue } \\
\text { IPO }\end{array}$ & United Kingdom: & $\begin{array}{l}1 \text { Issue } \\
\text { SEO }\end{array}$ \\
\hline \multicolumn{2}{|c|}{$\begin{array}{l}\text { * Emerging Markets } \\
\text { Total: } 35 \text { Issues from } 18 \text { Countries }\end{array}$} & & \\
\hline
\end{tabular}


Table 2

Early Return Performance By Day For Manufacturing Firm ADRs Issued From January 1990 Through December 2002 on the NYSE*

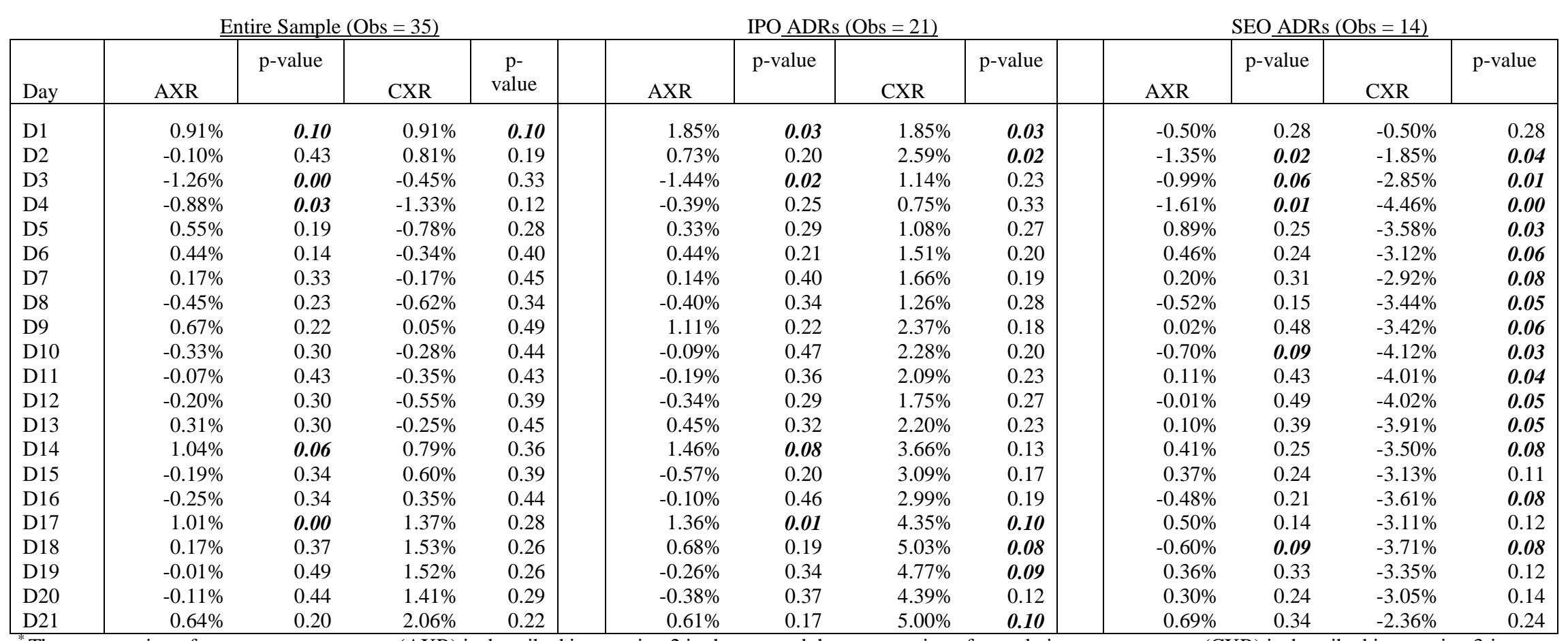

The computation of average excess returns (AXR) is described in equation 2 in the text and the computation of cumulative excess returns (CXR) is described in equation 3 in the text. P-values in bold italics represent returns that are significant at the $10 \%$ alpha level. 
Table 3

Early Return Performance By Day For Manufacturing Firm ADRs Issued From January 1990 Through December 2002 on the NYSE*

\begin{tabular}{|c|c|c|c|c|c|c|c|c|c|c|c|c|}
\hline \multicolumn{5}{|c|}{ Entire Sample $(\mathrm{Obs}=35)$} & \multicolumn{4}{|c|}{ Emerging Market ADRs $(\mathrm{Obs}=10)$} & \multicolumn{4}{|c|}{ Developed Market ADRs $(\mathrm{Obs}=25)$} \\
\hline Day & AXR & p-value & CXR & $\begin{array}{c}\text { p- } \\
\text { value }\end{array}$ & AXR & p-value & CXR & p-value & AXR & p-value & CXR & p-value \\
\hline D1 & $0.91 \%$ & 0.10 & $0.91 \%$ & 0.10 & $-0.03 \%$ & 0.48 & $-0.03 \%$ & 0.48 & $1.29 \%$ & 0.09 & $1.29 \%$ & 0.09 \\
\hline D2 & $-0.10 \%$ & 0.43 & $0.81 \%$ & 0.19 & $-1.20 \%$ & 0.00 & $-1.23 \%$ & 0.03 & $0.34 \%$ & 0.34 & $1.63 \%$ & 0.10 \\
\hline D3 & $-1.26 \%$ & 0.00 & $-0.45 \%$ & 0.33 & $-0.55 \%$ & 0.19 & $-1.78 \%$ & 0.02 & $-1.55 \%$ & 0.01 & $0.08 \%$ & 0.48 \\
\hline D4 & $-0.88 \%$ & 0.03 & $-1.33 \%$ & 0.12 & $-0.08 \%$ & 0.46 & $-1.86 \%$ & 0.07 & $-1.20 \%$ & 0.01 & $-1.12 \%$ & 0.23 \\
\hline D5 & $0.55 \%$ & 0.19 & $-0.78 \%$ & 0.28 & $0.73 \%$ & 0.04 & $-1.13 \%$ & 0.20 & $0.48 \%$ & 0.29 & $-0.65 \%$ & 0.36 \\
\hline D6 & $0.44 \%$ & 0.14 & $-0.34 \%$ & 0.40 & $-0.50 \%$ & 0.06 & $-1.63 \%$ & 0.12 & $0.82 \%$ & 0.06 & $0.18 \%$ & 0.46 \\
\hline D7 & $0.17 \%$ & 0.33 & $-0.17 \%$ & 0.45 & $0.53 \%$ & 0.18 & $-1.10 \%$ & 0.23 & $0.02 \%$ & 0.48 & $0.20 \%$ & 0.46 \\
\hline D8 & $-0.45 \%$ & 0.23 & $-0.62 \%$ & 0.34 & $0.24 \%$ & 0.33 & $-0.86 \%$ & 0.29 & $-0.72 \%$ & 0.19 & $-0.52 \%$ & 0.40 \\
\hline D9 & $0.67 \%$ & 0.22 & $0.05 \%$ & 0.49 & $0.04 \%$ & 0.47 & $-0.82 \%$ & 0.31 & $0.93 \%$ & 0.22 & $0.40 \%$ & 0.43 \\
\hline D10 & $-0.33 \%$ & 0.30 & $-0.28 \%$ & 0.44 & $0.68 \%$ & 0.17 & $-0.14 \%$ & 0.47 & $-0.74 \%$ & 0.19 & $-0.33 \%$ & 0.45 \\
\hline D11 & $-0.07 \%$ & 0.43 & $-0.35 \%$ & 0.43 & $0.94 \%$ & 0.02 & $0.80 \%$ & 0.34 & $-0.48 \%$ & 0.18 & $-0.81 \%$ & 0.38 \\
\hline D12 & $-0.20 \%$ & 0.30 & $-0.55 \%$ & 0.39 & $0.75 \%$ & 0.14 & $1.56 \%$ & 0.22 & $-0.59 \%$ & 0.10 & $-1.40 \%$ & 0.30 \\
\hline D13 & $0.31 \%$ & 0.30 & $-0.25 \%$ & 0.45 & $-0.07 \%$ & 0.44 & $1.49 \%$ & 0.24 & $0.46 \%$ & 0.28 & $-0.94 \%$ & 0.37 \\
\hline D14 & $1.04 \%$ & 0.06 & $0.79 \%$ & 0.36 & $0.17 \%$ & 0.43 & $1.66 \%$ & 0.23 & $1.38 \%$ & 0.06 & $0.45 \%$ & 0.44 \\
\hline D15 & $-0.19 \%$ & 0.34 & $0.60 \%$ & 0.39 & $-0.37 \%$ & 0.28 & $1.29 \%$ & 0.29 & $-0.12 \%$ & 0.42 & $0.32 \%$ & 0.46 \\
\hline D16 & $-0.25 \%$ & 0.34 & $0.35 \%$ & 0.44 & $-0.45 \%$ & 0.33 & $0.83 \%$ & 0.37 & $-0.17 \%$ & 0.41 & $0.16 \%$ & 0.48 \\
\hline D17 & $1.01 \%$ & 0.00 & $1.37 \%$ & 0.28 & $1.11 \%$ & 0.05 & $1.94 \%$ & 0.23 & $0.98 \%$ & 0.02 & $1.13 \%$ & 0.36 \\
\hline D18 & $0.17 \%$ & 0.37 & $1.53 \%$ & 0.26 & $-0.71 \%$ & 0.18 & $1.24 \%$ & 0.33 & $0.52 \%$ & 0.21 & $1.65 \%$ & 0.30 \\
\hline D19 & $-0.01 \%$ & 0.49 & $1.52 \%$ & 0.26 & $-2.40 \%$ & 0.00 & $-1.16 \%$ & 0.35 & $0.95 \%$ & 0.03 & $2.60 \%$ & 0.21 \\
\hline D20 & $-0.11 \%$ & 0.44 & $1.41 \%$ & 0.29 & $-1.08 \%$ & 0.09 & $-2.25 \%$ & 0.23 & $0.28 \%$ & 0.39 & $2.88 \%$ & 0.19 \\
\hline D21 & $0.64 \%$ & 0.20 & $2.06 \%$ & 0.22 & $-0.24 \%$ & 0.43 & $-2.48 \%$ & 0.23 & $1.00 \%$ & 0.14 & $3.87 \%$ & 0.13 \\
\hline
\end{tabular}

*The computation of average excess returns (AXR) is described in equation 2 in the text and the computation of cumulative excess returns (CXR) is described in equation 3 in the text. P-values in bold italics represent returns that are significant at the $10 \%$ alpha level. 
Table 4

Market-Timing Related Long-Term Performance by Month for Manufacturing Firm ADRs Listed on the NYSE

\begin{tabular}{|c|c|c|c|c|c|c|c|c|c|c|c|c|}
\hline \multirow[b]{3}{*}{ Month } & \multicolumn{12}{|c|}{ 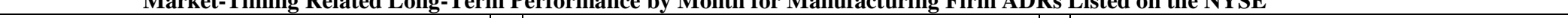 } \\
\hline & \multicolumn{4}{|c|}{ Entire Sample (35 Observations) } & \multicolumn{4}{|c|}{ ADRs Listed Before 1/1/98 (19 Observations) } & \multicolumn{4}{|c|}{ ADRs Listed After 1/1/98 (16 Observations) } \\
\hline & AXR & P-value & CXR & P-value & AXR & P-value & CXR & P-value & AXR & P-value & CXR & P-value \\
\hline+1 & $2.10 \%$ & 0.19 & $2.10 \%$ & 0.19 & $3.51 \%$ & 0.14 & $3.51 \%$ & 0.14 & $0.42 \%$ & 0.45 & $0.42 \%$ & 0.45 \\
\hline+2 & $2.71 \%$ & 0.18 & $4.81 \%$ & 0.10 & $0.83 \%$ & 0.40 & $4.34 \%$ & 0.18 & $4.94 \%$ & 0.17 & $5.36 \%$ & 0.19 \\
\hline+3 & $0.27 \%$ & 0.46 & $5.08 \%$ & 0.14 & $-3.10 \%$ & 0.22 & $1.24 \%$ & 0.42 & $4.28 \%$ & 0.11 & $9.64 \%$ & 0.08 \\
\hline+4 & $5.36 \%$ & 0.08 & $10.45 \%$ & 0.04 & $2.16 \%$ & 0.29 & $3.40 \%$ & 0.32 & $9.17 \%$ & 0.10 & $18.81 \%$ & 0.03 \\
\hline+5 & $0.64 \%$ & 0.35 & $11.08 \%$ & 0.04 & $4.18 \%$ & 0.03 & $7.58 \%$ & 0.16 & $-3.57 \%$ & 0.05 & $15.24 \%$ & 0.07 \\
\hline+6 & $0.14 \%$ & 0.48 & $11.23 \%$ & 0.05 & $-7.19 \%$ & 0.02 & $0.39 \%$ & 0.48 & $8.84 \%$ & 0.03 & $24.09 \%$ & 0.02 \\
\hline+7 & $-2.47 \%$ & 0.20 & $8.75 \%$ & 0.13 & $-4.00 \%$ & 0.21 & $-3.61 \%$ & 0.36 & $-0.65 \%$ & 0.41 & $23.44 \%$ & 0.02 \\
\hline+8 & $-2.33 \%$ & 0.13 & $6.42 \%$ & 0.21 & $-3.50 \%$ & 0.13 & $-7.11 \%$ & 0.25 & $-0.95 \%$ & 0.37 & $22.49 \%$ & 0.03 \\
\hline+9 & $-2.07 \%$ & 0.21 & $4.36 \%$ & 0.30 & $-0.79 \%$ & 0.41 & $-7.90 \%$ & 0.23 & $-3.58 \%$ & 0.19 & $18.91 \%$ & 0.07 \\
\hline+10 & $-1.51 \%$ & 0.22 & $2.85 \%$ & 0.37 & $-0.24 \%$ & 0.46 & $-8.14 \%$ & 0.23 & $-3.02 \%$ & 0.17 & $15.89 \%$ & 0.11 \\
\hline+11 & $-0.18 \%$ & 0.46 & $2.67 \%$ & 0.38 & $-1.95 \%$ & 0.27 & $-10.09 \%$ & 0.19 & $1.93 \%$ & 0.18 & $17.82 \%$ & 0.09 \\
\hline+12 & $-2.43 \%$ & 0.25 & $0.24 \%$ & 0.49 & $1.93 \%$ & 0.31 & $-8.15 \%$ & 0.25 & $-7.62 \%$ & 0.12 & $10.20 \%$ & 0.25 \\
\hline+13 & $0.49 \%$ & 0.41 & $0.73 \%$ & 0.47 & $-0.66 \%$ & 0.41 & $-8.82 \%$ & 0.24 & $1.86 \%$ & 0.24 & $12.06 \%$ & 0.21 \\
\hline+14 & $3.67 \%$ & 0.04 & $4.40 \%$ & 0.33 & $1.23 \%$ & 0.30 & $-7.59 \%$ & 0.28 & $6.58 \%$ & 0.03 & $18.64 \%$ & 0.12 \\
\hline+15 & $-0.72 \%$ & 0.39 & $3.68 \%$ & 0.36 & $-0.81 \%$ & 0.41 & $-8.40 \%$ & 0.26 & $-0.61 \%$ & 0.43 & $18.03 \%$ & 0.13 \\
\hline+16 & $-4.66 \%$ & 0.03 & $-0.98 \%$ & 0.46 & $-5.21 \%$ & 0.09 & $-13.61 \%$ & 0.16 & $-4.01 \%$ & 0.08 & $14.02 \%$ & 0.19 \\
\hline+17 & $0.17 \%$ & 0.47 & $-0.81 \%$ & 0.47 & $-0.73 \%$ & 0.41 & $-14.34 \%$ & 0.16 & $1.24 \%$ & 0.31 & $15.26 \%$ & 0.18 \\
\hline+18 & $2.74 \%$ & 0.13 & $1.93 \%$ & 0.43 & $0.45 \%$ & 0.45 & $-13.89 \%$ & 0.17 & $5.46 \%$ & 0.02 & $20.72 \%$ & 0.11 \\
\hline+19 & $-4.46 \%$ & 0.03 & $-2.52 \%$ & 0.41 & $-4.96 \%$ & 0.08 & $-18.85 \%$ & 0.11 & $-3.86 \%$ & 0.09 & $16.86 \%$ & 0.16 \\
\hline+20 & $4.27 \%$ & 0.03 & $1.75 \%$ & 0.44 & $5.45 \%$ & 0.05 & $-13.39 \%$ & 0.19 & $2.86 \%$ & 0.17 & $19.72 \%$ & 0.13 \\
\hline+21 & $0.79 \%$ & 0.32 & $2.54 \%$ & 0.41 & $0.71 \%$ & 0.39 & $-12.69 \%$ & 0.21 & $0.90 \%$ & 0.35 & $20.62 \%$ & 0.12 \\
\hline+22 & $1.67 \%$ & 0.13 & $4.21 \%$ & 0.36 & $0.81 \%$ & 0.38 & $-11.88 \%$ & 0.23 & $2.69 \%$ & 0.02 & $23.31 \%$ & 0.09 \\
\hline+23 & $-0.84 \%$ & 0.33 & $3.37 \%$ & 0.39 & $2.68 \%$ & 0.17 & $-9.20 \%$ & 0.28 & $-5.01 \%$ & 0.02 & $18.30 \%$ & 0.15 \\
\hline+24 & $-1.50 \%$ & 0.20 & $1.87 \%$ & 0.44 & $-1.90 \%$ & 0.21 & $-11.10 \%$ & 0.25 & $-1.03 \%$ & 0.35 & $17.27 \%$ & 0.17 \\
\hline+25 & $1.07 \%$ & 0.26 & $2.94 \%$ & 0.40 & $2.36 \%$ & 0.09 & $-8.74 \%$ & 0.30 & $-0.45 \%$ & 0.44 & $16.82 \%$ & 0.18 \\
\hline+26 & $1.45 \%$ & 0.22 & $4.39 \%$ & 0.36 & $-1.12 \%$ & 0.32 & $-9.86 \%$ & 0.28 & $4.49 \%$ & 0.06 & $21.31 \%$ & 0.12 \\
\hline+27 & $-0.59 \%$ & 0.36 & $3.80 \%$ & 0.38 & $1.83 \%$ & 0.21 & $-8.03 \%$ & 0.32 & $-3.47 \%$ & 0.07 & $17.84 \%$ & 0.17 \\
\hline+28 & $1.12 \%$ & 0.26 & $4.91 \%$ & 0.35 & $-0.96 \%$ & 0.36 & $-8.99 \%$ & 0.30 & $3.58 \%$ & 0.04 & $21.42 \%$ & 0.12 \\
\hline+29 & $-1.40 \%$ & 0.23 & $3.51 \%$ & 0.39 & $-3.01 \%$ & 0.15 & $-11.99 \%$ & 0.24 & $0.51 \%$ & 0.41 & $21.92 \%$ & 0.12 \\
\hline+30 & $0.34 \%$ & 0.42 & $3.85 \%$ & 0.38 & $0.82 \%$ & 0.36 & $-11.17 \%$ & 0.26 & $-0.23 \%$ & 0.46 & $21.69 \%$ & 0.13 \\
\hline+31 & $-1.50 \%$ & 0.15 & $2.35 \%$ & 0.43 & $-2.08 \%$ & 0.14 & $-13.25 \%$ & 0.22 & $-0.82 \%$ & 0.36 & $20.87 \%$ & 0.14 \\
\hline+32 & $-1.69 \%$ & 0.12 & $0.66 \%$ & 0.48 & $-1.81 \%$ & 0.17 & $-15.06 \%$ & 0.19 & $-1.55 \%$ & 0.25 & $19.32 \%$ & 0.16 \\
\hline+33 & $-0.87 \%$ & 0.35 & $-0.21 \%$ & 0.49 & $-3.88 \%$ & 0.12 & $-18.94 \%$ & 0.14 & $2.71 \%$ & 0.19 & $22.04 \%$ & 0.13 \\
\hline+34 & $-1.16 \%$ & 0.30 & $-1.37 \%$ & 0.46 & $-1.43 \%$ & 0.32 & $-20.37 \%$ & 0.13 & $-0.85 \%$ & 0.41 & $21.19 \%$ & 0.14 \\
\hline+35 & $-3.75 \%$ & 0.01 & $-5.12 \%$ & 0.35 & $-4.80 \%$ & 0.00 & $-25.17 \%$ & 0.08 & $-2.49 \%$ & 0.20 & $18.70 \%$ & 0.17 \\
\hline+36 & $0.88 \%$ & 0.34 & $-4.24 \%$ & 0.38 & $-1.34 \%$ & 0.33 & $-26.51 \%$ & 0.08 & $3.52 \%$ & 0.11 & $22.21 \%$ & 0.13 \\
\hline
\end{tabular}

${ }^{4}$ See footnote to Table 2 . 


\section{REFERENCES}

1. Aggarwal, R., R. Leal and L. Hernandez. 1993. The Aftermarket Performance of Initial Public Offerings in Latin America. Financial Management. 22: 42-53.

2. Alexander, Gordon J., Cheol S. Eun, and S. Janakiramanan. 1988. International Listings and Stock Returns: Some Empirical Evidence. Journal of Financial and Quantitative Analysis. 135-151.

3. Ben Naceur, S. 2000. An Examination of the Tunisian IPO Pricing in the Short and Long Run: 1992-1997. Applied Economics Letters. 7: 293-296.

4. Besley, Scott and Eugene F. Brigham. 1999. Principles of Finance. The Dryden Press, New York. 126.

5. Brav, A. and P. Gompers. 1997. Myth or Reality? The Long-Run Underperformance of Initial Public Offerings: Evidence from Venture and Non-venture Capital-Backed Companies. Journal of Finance. 52: 1791-1821.

6. Brigham, Eugene, F. and Michael C. Ehrhardt. 2005. Financial Management, 11 Edition, South-Western Publishers, Mason, Ohio. 900.

7. Callaghan, J., R. Kleiman and A. Sahu. 1999. The Market-Adjusted Investment Performance of ADR IPOs and SEOs. Global Finance Journal. 10: 123-145.

8. Cox, W. Michael, and Richard Alm. 2002. The Fruits of Free Trade. 2002 Annual Report, Federal Reserve Bank of Dallas. 23-24.

9. Cox, W. Michael, and Richard Alm. 2005. Racing to the Top: How Global Competition Disciplines Public Policy. 2005 Annual Report, Federal Reserve Bank of Dallas. 4-18.

10. Cox, W. Michael, and Richard Alm. 2006. The Best of All Worlds: Globalizing the Knowledge Economy. 2006 Annual Report, Federal Reserve Bank of Dallas. 26-27.

11. Dawson, S. 1987. The Secondary Stock Market Performance of Initial Public Offerings in Hong Kong, Singapore and Malaysia: 1978-1984. Journal of Business, Finance \& Accounting. 14: 65-76.

12. Elliott, S. and Mark Schaub. 2005. Foreign Financial Institution Equities: Returns From Emerging Markets and Developed Markets Differ. International Business \& Economics Research Journal. 4: 13-20.

13. Engardio, Pete and Armdt, Michael. 2006. The Future of Outsourcing. Business Week. January 30.

14. Foerster, S. and G. Andrew Karolyi. 2000. The Long-Run Performance of Global Equity Offerings. Journal of Financial and Quantitative Analysis. 35: 499-528.

15. Huang, Y. 1999. The Price Behavior of Initial Public Offerings on the Taiwan Stock Exchange. Applied Financial Economics. 9: 201-208.

16. Jayaraman, N., K. Shastri, and K. Tandon. 1993. The Impact of International Cross Listings on Risk and Return: The Evidence From American Depository Receipts. Journal of Banking \& Finance. 17: 91-103.

17. Jiang, C. 1998. Diversification with American Depository Receipts: The Dynamics and the Pricing Factors. Journal of Business, Finance \& Accounting. 25: 683-699.

18. Levis, M. 1993. The Long-Run Performance of Initial Public Offerings: The UK Experience 1980-1988. Financial Management. 22: 28-42.

19. Martell, T., L. Rodriguez, Jr. and G. Webb. Fall/Winter1999. The Impact of Listing Latin American ADRs on the Risks and Returns of the Underlying Shares. Global Finance Journal. 10: 147-160.

20. Officer, D. and R. Hoffmeister. 1988. ADRs: A Substitute for the Real Thing? Journal of Portfolio Management. 15: 61-65.

21. Ritter, J. 1991. The Long-Run Performance of Initial Public Offerings. Journal of Finance. 46: 3-27.

22. Schaub, M. 2002. Hazardous to Your Wealth? The Early and Long-Term Performance of Mexican ADRs on the New York Stock Exchange. Journal of Asset Management. 3: 9-16.

23. Schaub, M. 2003a. The Early Performance of American Depository Receipts on the New Business and York Stock Exchange during 2000-2001 Bull to Bear Market Transition. Southern Business and Economic Journal. 25: 78-90.

24. Schaub, M. 2003b. Investment Performance of American Depository Receipts Listed on the New York Stock Exchange: Long and Short. Journal of Business and Economic Studies. 9:1-19.

25. Schaub, M. 2004. Short-Term and Long-Term Performance of IPOs and SEOs Traded as American Depository Receipts: Does Timing Matter? Journal of Asset Management. 5: 263-271. 
26. Schaub, M. 2006.Market Timing Wealth Effects of American Depository Receipts: The Cases of Emerging and Developed Market Issues. Journal of International Financial Markets, Institutions \& Money. 16: $270-282$.

27. Sundaram, A. and D. Logue. 1996. Valuation Effects of Foreign Company Listings on U.S. Exchanges. Journal of International Business Studies. 27: 67-89.

28. Surz, Ronald J. 2007. Stock Diversification in the $21^{\text {st }}$ Century. Journal of Financial Service Professionals. 61: 14-17.

\section{NOTES}




\section{NOTES}

